\title{
Chemical Composition, Antioxidant and Enzyme Inhibitory Activities of Onosma bourgaei and Onosma trachytricha and in Silico Molecular Docking Analysis of Dominant Compounds
}

\author{
Erman Salih Istifli
}

check for updates

Citation: Istifli, E.S. Chemical Composition, Antioxidant and Enzyme Inhibitory Activities of Onosma bourgaei and Onosma trachytricha and in Silico Molecular Docking Analysis of Dominant Compounds. Molecules 2021, 26, 2981. https://doi.org/10.3390/ molecules 26102981

Academic Editors: Ekaterina Yurchenko and Dmitry Aminin

Received: 5 April 2021

Accepted: 12 May 2021

Published: 18 May 2021

Publisher's Note: MDPI stays neutral with regard to jurisdictional claims in published maps and institutional affiliations.

Copyright: (C) 2021 by the author. Licensee MDPI, Basel, Switzerland. This article is an open access article distributed under the terms and conditions of the Creative Commons Attribution (CC BY) license (https:/ / creativecommons.org/licenses/by/ $4.0 /)$.
Department of Biology, Faculty of Science and Literature, Cukurova University, TR-01330 Adana, Turkey; esistifli@cu.edu.tr; Tel.: +90-537-437-05-67

\begin{abstract}
The aim of this study was to investigate the chemical composition, antioxidant and enzyme inhibitory activities of methanol (MeOH) extracts from Onosma bourgaei (Boiss.) and O. trachytricha (Boiss.). In addition, the interactions between phytochemicals found in extracts in high amounts and the target enzymes in question were revealed at the molecular scale by performing in silico molecular docking simulations. While the total amount of flavonoid compounds was higher in O. bourgaei, O. trachytricha was richer in phenolics. Chromatographic analysis showed that the major compounds of the extracts were luteolin 7-glucoside, apigenin 7-glucoside and rosmarinic acid. With the exception of the ferrous ion chelating assay, O. trachytricha exhibited higher antioxidant activity than O. bourgaei. O. bourgaei exhibited also slightly higher activity on digestive enzymes. The inhibitory activities of the Onosma species on tyrosinase were almost equal. In addition, the inhibitory activities of the extracts on acetylcholinesterase (AChE) were stronger than the activity on butyrylcholinesterase (BChE). Molecular docking simulations revealed that luteolin 7-glucoside and apigenin 7-glucoside have particularly strong binding affinities against $\mathrm{ChEs}$, tyrosinase, $\alpha$-amylase and $\alpha$-glucosidase when compared with co-crystallized inhibitors. Therefore, it was concluded that the compounds in question could act as effective inhibitors on cholinesterases, tyrosinase and digestive enzymes.
\end{abstract}

Keywords: Onosma bourgaei; Onosma trachytricha; LC-MS/MS; antioxidant; enzyme inhibition; molecular docking

\section{Introduction}

The members of the Boraginaceae are mainly spread in tropical regions of the world. According to the taxonomic records, this genus is estimated to consist of 100 genera and 2000 species spread throughout the Earth [1,2]. Many Onosma species have been scrutinized to determine their biologically active substances such as deoxyshikonin, acetyl shikonin, 3-hydroxyisovaleryl shikonin and 5,8-O-dimethylacetyl shikonin [2]. Shikonin derivatives, known to be produced by some members of Onosma, are used as natural dyes due to their red color and have also been used in the silk and food industries since ancient times [3-5]. The cultivation of Onosma species, therefore, is of great importance. Additionally, many Onosma species have been found to have several activities such as antioxidant, antimicrobial, wound healing [6,7], and anti-tumor [7]. On the other hand, some Onosma species (O. argentatum, O. echiodes, $O$. heterophylla, and $O$. stellulatum) have been reported to contain alkaloids showing carcinogenic and/or hepatotoxic properties [8,9].

Antioxidant activity is one of the most important pharmacological properties of plants and plants are rich sources of antioxidant phytochemicals. Many researchers agree that oxidative stress is strongly correlated with the pathology of many diseases [10]. Antioxidants provide significant advantages in dealing with the negative effects of oxidative stress on the body. Polyphenols are phytochemicals that stand out with their antioxidant activities and are abundant in many vegetables and fruits that we consume in our daily 
lives [10]. Scientific studies have shown that consuming foods rich in polyphenols reduces the risk of many common diseases such as degenerative disorders, diabetes, cardiovascular diseases, and cancer [10-13]. Polyphenols not only protect the body from oxidative stress, but also known to exhibit significant inhibitory activity on $\alpha$-glucosidase and $\alpha$-amylase, the enzymes responsible for carbohydrate digestion. Inhibition of these enzymes is considered to be an important approach in medical treatment as they suppress postprandial hyperglycemia in diabetic patients [14]. Therefore, it is thought that the determination of new plant species and bioactive compounds that have an inhibitory effect on these enzymes will lead to promising advances in the treatment of diabetes [15].

In addition to the inhibition of digestive enzymes mentioned above, plants also have numerous phytochemicals showing tyrosinase inhibitory activity, which has become increasingly popular in recent years. Melanin is an important barrier that protects our body against harmful rays [16]. The synthesis of this pigment is catalyzed by tyrosinase under the stimulation of UV rays $[17,18]$. Excessive melanin synthesis leads to hyperpigmentationrelated disorders. [19]. Excessive melanin synthesis can be prevented through the use of tyrosinase inhibitors. Tyrosinase inhibitors are one of the newest approaches used in the cosmetic industry today to whiten the skin. It is known that kojic acid, mercury, hydroquinone, and arbutin, whose tyrosinase inhibitor activities are well-characterized, have serious side effects on our body in long-term use. For this reason, both the leading companies of the cosmetics industry and researchers have focused on discovering new and more effective phytochemicals that do not cause serious adverse effects in the human body [20].

Acetylcholine $(\mathrm{ACh})$ is an important neurotransmitter responsible for the regulation of normal memory functions [21]. However, the amount of this substance can decrease dramatically, especially in the elderly individuals, due to the hydrolysis by cholinesterases (ChEs), which are responsible for the regulation of the amount of ACh [22]. Therefore, inhibition of ChEs is a useful strategy in these individuals in order to prevent the decrease in the amount of neurotransmitters and to stabilize cognitive functions [5,23-28].

The purpose of this study was to determine the chemical composition of methanol $(\mathrm{MeOH})$ extracts obtained from O. bourgaei (Boiss.) and O. trachytricha (Boiss.) and to compare their antioxidant and enzyme inhibitor activities on $\alpha$-amylase, $\alpha$-glucosidase, tyrosinase and ChEs. In addition, to provide further insights into enzyme inhibitory activity, interactions between dominant compounds and enymes in question were studied via molecular docking.

\section{Results}

\subsection{Antioxidant Activity of the Extracts}

The antioxidant activities of the $\mathrm{MeOH}$ extracts of Onosma species were analyzed using phosphomolybdenum, DPPH and ABTS radical scavenging, CUPRAC and FRAP reducing power potential and ferrous ion chelating assay techniques (Figure 1). O. trachytricha exhibited higher antioxidant activity than O. bourgaei in all parameters except ferrous ion chelating assay. Phosphomolybdenum, DPPH and ABTS scavenging and CUPRAC and FRAP reducing potentials of $O$. trachytricha were determined as 536.69, 163.92, 213.88, 340.78 , and $195.50 \mathrm{mg}$ TEs/g extract, respectively. However, in chelating activity assay, the activity of $O$. bourgaei (24.85 mg EDTAEs/g extract) was higher than that of $O$. trachytricha (10.33 mg EDTAEs/g extract). The higher activity of $O$. trachytricha which was richer in the selected phytochemicals, in most of the antioxidant activity tests showed that the chemical composition contributed to the antioxidant activity significantly. In all of the antioxidant activity tests, both extracts exhibited different activities that are statistically significant. 


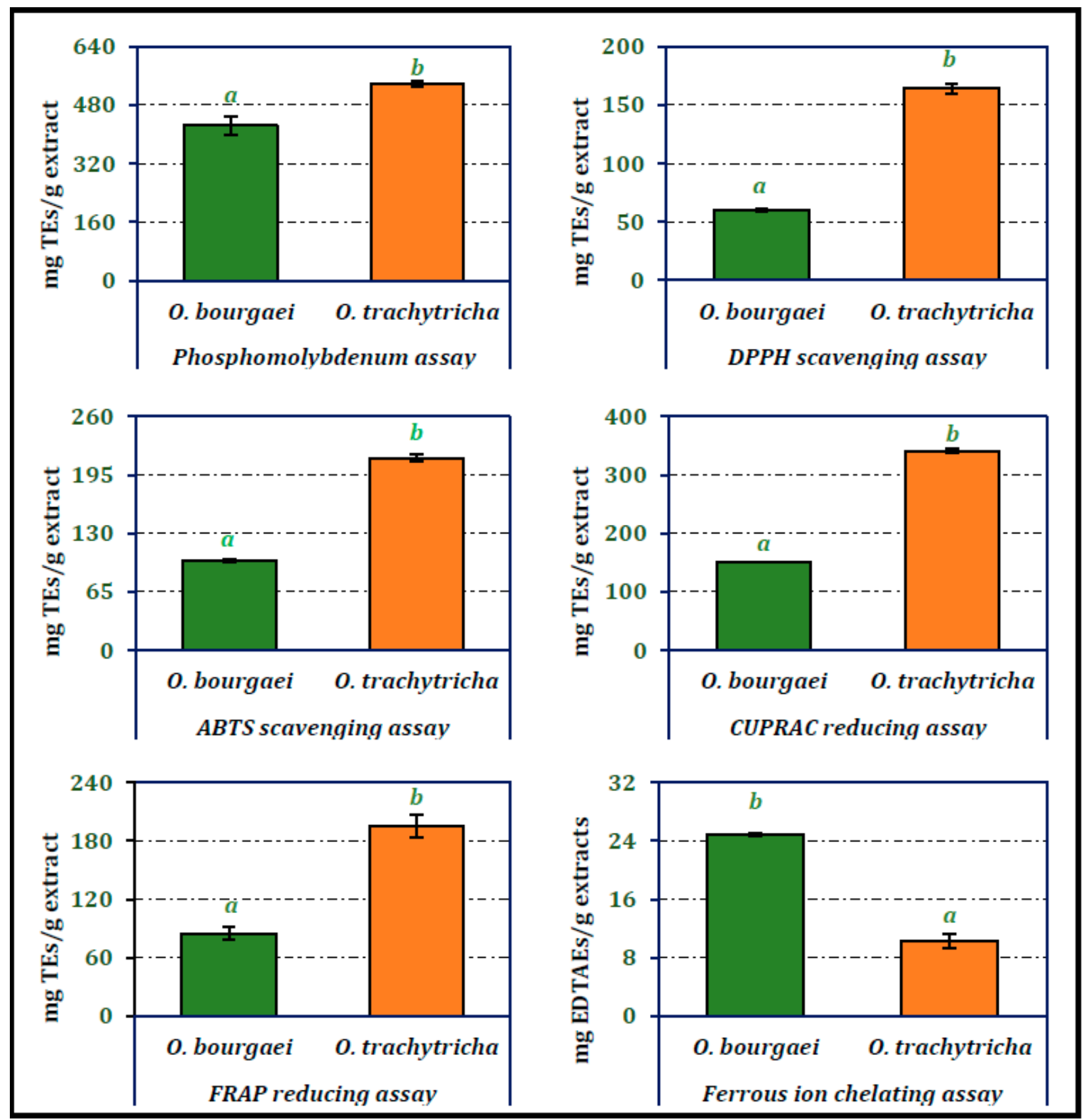

Figure 1. Total antioxidant, radical scavenging, reducing power and chelating activity of the MeOH extracts of O. bourgaei and O. trachytricha [TEs: Trolox equivalents, EDTAEs: Ethylenediaminetetraacetic acid (disodium salt)]. Data with different superscripts $(a, b)$ were different from each other. All tests were performed in triplicate.

\subsection{Enzyme Inhibitory Activity of the Extracts}

Inhibitory activities of the $\mathrm{MeOH}$ extracts obtained from O. bourgaei and O. trachytricha on $\alpha$-glucosidase, $\alpha$-amylase, tyrosinase, $\mathrm{AChE}$ and $\mathrm{BChE}$ are presented in Figure 2. O. bourgaei exhibited higher inhibitory activity on digestive enzymes than other Onosma species (902.99 and $361.64 \mathrm{mg}$ ACEs/g extract, respectively). The activity of the extracts on tyrosinase was almost equal. $O$. trachytricha exhibited higher inhibitory activity on both cholinesterases than O. bourgaei (2.21 and $0.58 \mathrm{mg}$ GALAEs/g extract, respectively). Furthermore, in BChE inhibitor activity assay, the inhibitory activity of $O$. trachytricha was more than two folds higher than that of $O$. bourgaei. 



Figure 2. Enzyme inhibition activities of the MeOH extracts of $O$. bourgaei and O. trachytricha (KAEs: Kojic acid equivalents, GALAEs: Galanthamine equivalents, ACEs: Acarbose equivalents). Data with different superscripts (a, b) were different from each other. All tests were performed in triplicate.

\subsection{Phytochemistry of O. bourgaei and O. trachytricha}

Chemical composition of Onosma species were analyzed using both qualitative and quantitative techniques. Total phenolic and flavonoid compounds of Onosma species were analyzed spectrophotometrically. According to data presented in Figure 3, O. bourgaei was richer in flavonoids, while O. trachytricha was found to contain higher amount of phenolics. The amounts of flavonoids in the extracts were 39.92 and $29.09 \mathrm{mg}$ QEs / g extract, respectively. On the other hand, phenolic amounts of $\mathrm{MeOH}$ extracts were determined as 
28.05 and $43.97 \mathrm{mg}$ GAEs/g extract, respectively. The phenolic and flavonoid contents of each extract were statistically significantly different from each other.

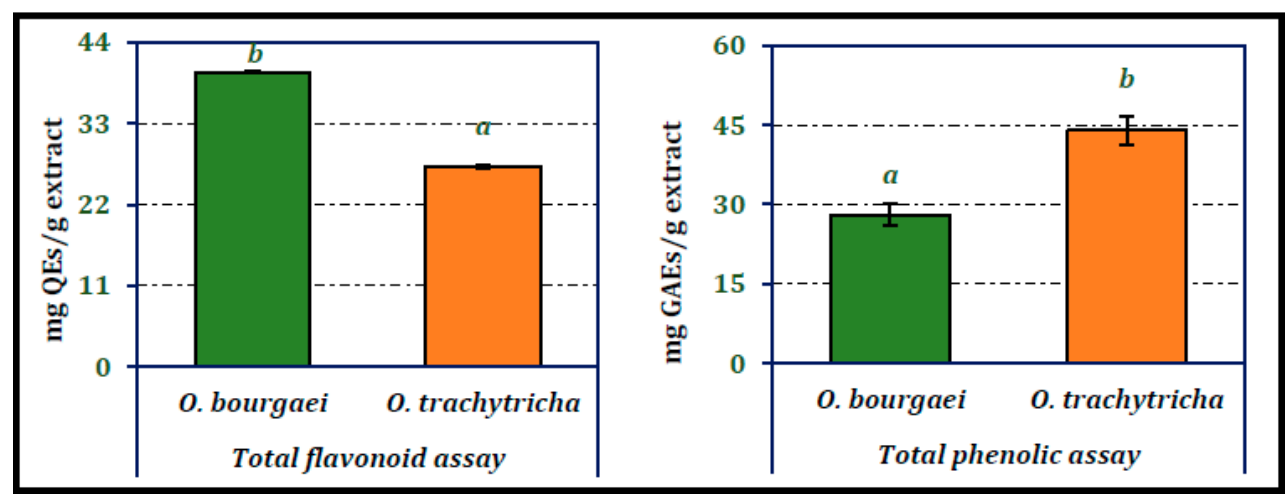

Figure 3. Total phenolic and flavonoid contents of the MeOH extracts of O. bourgaei and O. trachytricha (QEs: Quercetin equivalents, GAEs: Gallic acid equivalents). Data with different superscripts $(a, b)$ were different from each other. All tests were performed in triplicate.

Chromatographic analyzes were carried out to determine the amounts of some phytochemicals in the extracts. The analytical characteristics of these phytochemicals are presented in Table 1. The LC-MS/MS chromatograms of selected phytochemicals in $\mathrm{MeOH}$ extracts were given in Figure 4 and as $\mu \mathrm{g} / \mathrm{g}$ extract in Table 2. As can be seen from the chromatograms in Figure 4, the main compounds of both O. bourgaei and O. trachytricha were luteolin 7-glucoside (23,908.22 and 22,326.01 $\mu \mathrm{g} / \mathrm{g}$ extract, respectively), rosmarinic acid $(10,013.76$ and $24,837.51 \mu \mathrm{g} / \mathrm{g}$ extract, respectively) and apigenin 7-glucoside $(21,689.17$ and $17,949.03 \mu \mathrm{g} / \mathrm{g}$ extract, respectively). Many compounds selected were in high quantities in O. trachytricha extract. However, it was found that some phytochemicals such as pinoresinol, luteolin 7-glucoside, gallic acid, luteolin, eriodictyol, apigenin 7-glucoside, and verbascoside were in higher amounts in O. bourgaei extract than O. trachytricha.

Table 1. Analytical characteristics of selected phenolic compounds in the methanolic extracts from O. bourgaei and O. trachytricha $\mathrm{x}$.

\begin{tabular}{|c|c|c|c|c|c|}
\hline Rt (min) & Compounds & Linear Equation & $\mathbf{R}^{2}$ & $\begin{array}{c}\text { LOD } \\
(\mu \mathrm{g} / \mathrm{L})\end{array}$ & $\begin{array}{c}\mathrm{LOQ} \\
(\mu \mathrm{g} / \mathrm{L})\end{array}$ \\
\hline 8.891 & Gallic acid & $y=4.82 x-26.48$ & 0.9988 & 1.46 & 4.88 \\
\hline 10.818 & Protocatechuic acid & $y=5.65 x-9.99$ & 0.9990 & 1.17 & 3.88 \\
\hline 11.224 & 3,4-Dihydroxyphenylacetic acid & $y=5.13 x-12.39$ & 0.9990 & 1.35 & 4.51 \\
\hline 11.369 & $(+)$-Catechin & $y=1.45 x+1.95$ & 0.9974 & 3.96 & 13.20 \\
\hline 11.506 & Pyrocatechol & $y=0.11 x-0.52$ & 0.9916 & 9.62 & 32.08 \\
\hline 11.802 & Chlorogenic acid & $y=12.14 x+32.34$ & 0.9995 & 0.55 & 1.82 \\
\hline 12.412 & 2,5-Dihydroxybenzoic acid & $y=3.79 x-14.12$ & 0.9980 & 2.12 & 7.08 \\
\hline 12.439 & 4-Hydroxybenzoic acid & $y=7.62 x+22.79$ & 0.9996 & 1.72 & 5.72 \\
\hline 12.458 & (-)-Epicatechin & $y=9.11 x-9.99$ & 0.9971 & 1.85 & 6.18 \\
\hline 12.841 & Caffeic acid & $y=11.09 x+16.73$ & 0.9997 & 3.15 & 10.50 \\
\hline 12.843 & Vanillic acid & $y=0.49 x-1.61$ & 0.9968 & 2.56 & 8.54 \\
\hline 12.963 & Syringic acid & $y=0.74 x-1.54$ & 0.9975 & 3.75 & 12.50 \\
\hline 13.259 & 3-Hydroxybenzoic acid & $y=3.69 x-12.29$ & 0.9991 & 1.86 & 6.20 \\
\hline 13.397 & Vanillin & $y=2.02 x+135.49$ & 0.9926 & 15.23 & 50.77 \\
\hline 13.589 & Verbascoside & $y=8.59 x-28.05$ & 0.9988 & 0.82 & 2.75 \\
\hline 13.909 & Taxifolin & $y=12.32 x+9.98$ & 0.9993 & 1.82 & 6.05 \\
\hline 13.992 & Sinapic acid & $y=2.09 x-6.79$ & 0.9974 & 2.64 & 8.78 \\
\hline 14.022 & p-Coumaric acid & $y=17.51 x+53.73$ & 0.9997 & 1.93 & 6.44 \\
\hline 14.120 & Ferulic acid & $y=3.32 x-4.30$ & 0.9992 & 1.43 & 4.76 \\
\hline 14.266 & Luteolin-7-glucoside & $y=45.25 x+156.48$ & 0.9996 & 0.45 & 1.51 \\
\hline
\end{tabular}


Table 1. Cont

\begin{tabular}{|c|c|c|c|c|c|}
\hline Rt (min) & Compounds & Linear Equation & $\mathbf{R}^{2}$ & $\begin{array}{c}\text { LOD } \\
(\mu \mathrm{g} / \mathrm{L})\end{array}$ & $\begin{array}{c}\mathrm{LOQ} \\
(\mu \mathrm{g} / \mathrm{L})\end{array}$ \\
\hline 14.412 & Hesperidin & $y=5.98 x+0.42$ & 0.9993 & 1.73 & 5.77 \\
\hline 14.506 & Hyperoside & $y=16.32 x-1.26$ & 0.9998 & 0.99 & 3.31 \\
\hline 14.600 & Rosmarinic acid & $y=9.82 x-17.98$ & 0.9989 & 0.57 & 1.89 \\
\hline 14.781 & Apigenin-7-glucoside & $y=21.33 x-31.69$ & 0.9983 & 0.41 & 1.35 \\
\hline 15.031 & 2-Hydroxycinnamic acid & $y=16.72 x-26.94$ & 0.9996 & 0.61 & 2.03 \\
\hline 15.118 & Pinoresinol & $y=0.80 x-2.69$ & 0.9966 & 3.94 & 13.12 \\
\hline 15.247 & Eriodictyol & $y=14.24 x-0.50$ & 0.9998 & 0.80 & 2.68 \\
\hline 15.668 & Quercetin & $y=14.68 x-18.25$ & 0.9997 & 1.23 & 4.10 \\
\hline 15.923 & Luteolin & $y=8.96 x+26.80$ & 0.9992 & 1.34 & 4.46 \\
\hline 16.236 & Kaempferol & $y=0.82 x-3.06$ & 0.9959 & 3.30 & 10.99 \\
\hline 16.382 & Apigenin & $y=11.29 x+38.05$ & 0.9987 & 0.96 & 3.20 \\
\hline
\end{tabular}

${ }^{x} \mathrm{Rt}$, retention time. LOD and LOQ: limit of detection and limit of quantification, respectively.

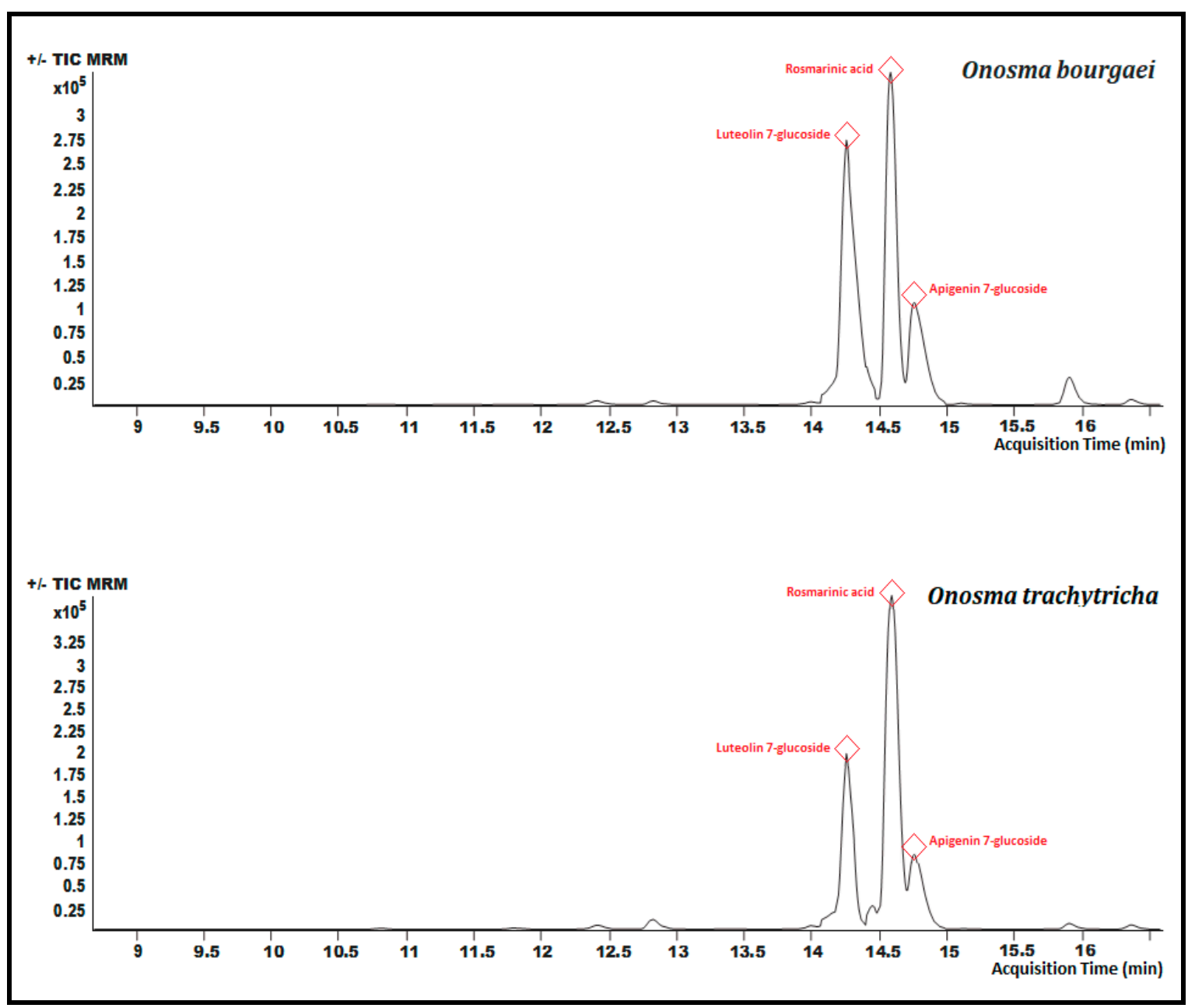

Figure 4. Chromatograms of the $\mathrm{MeOH}$ extracts of $\mathrm{O}$. bourgaei and O. trachytricha. The three major components were depicted in red color. 
Table 2. Amounts of selected compounds in Onosma species ${ }^{\mathrm{x}}$.

\begin{tabular}{|c|c|c|}
\hline Compound & O. bourgaei $(\mu \mathrm{g} / \mathrm{g})$ & O. trachytricha $(\mu \mathrm{g} / \mathrm{g})$ \\
\hline Gallic acid & $5.30 \pm 0.16^{\mathrm{a}}$ & $4.47 \pm 0.25^{\mathrm{a}}$ \\
\hline Protocatechuic acid & $35.53 \pm 0.57^{\mathrm{a}}$ & $138.34 \pm 2.44^{b}$ \\
\hline 3,4-Dihydroxyphenylacetic acid & nd & $11.40 \pm 0.29$ \\
\hline$(+)$-Catechin & nd & nd \\
\hline Pyrocatechol & nd & nd \\
\hline Chlorogenic acid & $18.52 \pm 0.39^{\mathrm{a}}$ & $136.40 \pm 10.35^{b}$ \\
\hline 2,5-Dihydroxybenzoic acid & $71.05 \pm 0.61^{\mathrm{a}}$ & $163.26 \pm 0.93^{b}$ \\
\hline 4-Hydroxybenzoic acid & $297.18 \pm 1.54^{\mathrm{a}}$ & $392.63 \pm 22.47^{b}$ \\
\hline (-)-Epicatechin & nd & nd \\
\hline Caffeic acid & $142.69 \pm 4.28^{\mathrm{a}}$ & $465.37 \pm 16.12^{b}$ \\
\hline Vanillic acid & $57.43 \pm 2.39^{a}$ & $943.21 \pm 14.90^{b}$ \\
\hline Syringic acid & $13.76 \pm 1.38^{\mathrm{a}}$ & $32.83 \pm 1.83^{b}$ \\
\hline 3-Hydroxybenzoic acid & $5.63 \pm 0.36^{\mathrm{a}}$ & $6.27 \pm 0.06^{\mathrm{a}}$ \\
\hline Vanillin & $13.83 \pm 0.96^{\mathrm{a}}$ & $127.75 \pm 3.12^{b}$ \\
\hline Verbascoside & $1.89 \pm 0.01$ & nd \\
\hline Taxifolin & nd & nd \\
\hline Sinapic acid & $18.72 \pm 0.41^{\mathrm{a}}$ & $39.65 \pm 2.26^{b}$ \\
\hline$p$-Coumaric acid & $58.46 \pm 0.39^{a}$ & $119.23 \pm 5.30^{b}$ \\
\hline Ferulic acid & $112.78 \pm 0.94^{\mathrm{a}}$ & $559.18 \pm 47.28^{b}$ \\
\hline Luteolin 7-glucoside & $23,908.22 \pm 922.89^{a}$ & $22,326.01 \pm 216.87^{\mathrm{a}}$ \\
\hline Hesperidin & $8.63 \pm 0.01^{\mathrm{a}}$ & $79.04 \pm 2.02^{b}$ \\
\hline Hyperoside & $19.47 \pm 0.10^{\mathrm{a}}$ & $120.51 \pm 4.32^{\mathrm{b}}$ \\
\hline Rosmarinic acid & $10,013.76 \pm 175.93^{a}$ & $24,837.51 \pm 1069.14^{b}$ \\
\hline Apigenin 7-glucoside & $21,689.17 \pm 215.93^{b}$ & $17,949.03 \pm 468.50^{\mathrm{a}}$ \\
\hline 2-Hydroxycinnamic acid & nd & nd \\
\hline Pinoresinol & $1224.04 \pm 1.94^{b}$ & $762.64 \pm 36.65^{a}$ \\
\hline Eriodictyol & $2.47 \pm 0.08$ & nd \\
\hline Quercetin & $2.75 \pm 0.06^{\mathrm{a}}$ & $3.21 \pm 0.23^{\mathrm{a}}$ \\
\hline Luteolin & $1890.26 \pm 85.62$ & nd \\
\hline Kaempferol & nd & $3.97 \pm 0.18$ \\
\hline Apigenin & $211.32 \pm 1.04^{\mathrm{a}}$ & $280.06 \pm 7.68^{b}$ \\
\hline
\end{tabular}

${ }^{x}$ Data with different superscripts $(a, b)$ within the same row were different from each other. nd-not detected.

\subsection{Molecular Docking Studies}

In this study, the results of molecular docking analysis of the three major phytochemicals with their binding affinities $(\mathrm{kcal} / \mathrm{mol})$ and inhibition constants $(\mathrm{mM})$ against $\mathrm{AChE}$, $\mathrm{BChE}$, tyrosinase, $\alpha$-amylase and $\alpha$-glucosidase were given in Table 3 . In addition, the binding affinity values of the inhibitors obtained by performing redocking of the co-crystallized ligands of these enzymes were used as positive control values for comparison. Luteolin 7-glucoside and apigenin 7-glucoside generally exhibited high binding affinities for these five enzymes. The binding affinities and inhibition constants of these two flavonoid glycosides were found to be comparable to or even more negative than the positive control of each enzyme (Table 3). Rosmarinic acid, on the other hand, displayed the most remarkable binding affinity for $\mathrm{BChE}$ enzyme $\left(\Delta \mathrm{G}^{\circ}=-7.91 \mathrm{kcal} / \mathrm{mol}\right)$, however, it did not show strong binding affinity as the positive control for the other four enzymes. Flavonoid glycosides (luteolin 7-glucoside and apigenin 7-glucoside), on the other hand, specifically exhibited noticeable binding affinity on the $\mathrm{AChE}, \mathrm{BChE}$, tyrosinase and digestive enzymes and these binding affinities were comparable to or even more negative than the positive controls (Table 3). The aminoacid residues in which the ligands interact within the inhibitor binding pockets of the enzymes $\mathrm{AChE}, \mathrm{BChE}$, tyrosinase, $\alpha$-amylase and $\alpha$-glucosidase are shown in Figures 5-9. The results obtained from molecular docking calculations show that luteolin 7-glucoside and apigenin 7-glucoside have particularly strong binding affinities when compared with co-crystallized inhibitors (galantamine, tacrine, kojic acid and acarbose) (Table 3). 
Table 3. Binding affinity (binding free energy) and calculated inhibition constant values of luteolin 7-glucoside, apigenin 7-glucoside and rosmarinic acid against enzymes in molecular docking simulations.

\begin{tabular}{cccc}
\hline \multirow{2}{*}{ Enzyme } & Ligand & $\begin{array}{c}\text { Binding Affinity } \\
\left(\Delta \mathbf{G}^{\circ} ; \mathbf{k c a l} / \mathbf{m o l}\right)\end{array}$ & $\begin{array}{c}\text { Inhibition Constant } \\
(\mathbf{m M})\end{array}$ \\
\hline \multirow{5}{*}{ AChE } & Galantamine & -7.25 & 0.0048 \\
& (inhibitor) & -8.92 & 0.0003 \\
& Luteolin 7-glucoside & -9.26 & 0.0001 \\
& Apigenin 7-glucoside & -6.72 & 0.0110 \\
& Rosmarinic acid & -6.93 & 0.0082 \\
& Tacrine (inhibitor) & -10.87 & 0.00001 \\
BChE & Luteolin 7-glucoside & -9.86 & 0.00006 \\
& Apigenin 7-glucoside & -7.91 & 0.0015 \\
& Rosmarinic acid & -5.64 & 0.0728 \\
& Kojic acid (inhibitor) & -5.83 & 0.0536 \\
& Luteolin 7-glucoside & -5.41 & 0.1081 \\
& Apigenin 7-glucoside & -4.58 & 0.4383 \\
& Rosmarinic acid & -10.4 & 0.00002 \\
& Acarbose (inhibitor) & -8.19 & 0.0009 \\
& Luteolin 7-glucoside & -7.64 & 0.0025 \\
& Apigenin 7-glucoside & -6.17 & 0.0301 \\
& Rosmarinic acid & -9.53 & 0.0001 \\
& Acarbose (inhibitor) & -9.22 & 0.0001 \\
& Luteolin 7-glucoside & -9.09 & 0.0002 \\
& Apigenin 7-glucoside & -5.26 & 0.139 \\
\hline \multirow{3}{*}{$\alpha$-Glucosidase } & Rosmarinic acid & &
\end{tabular}

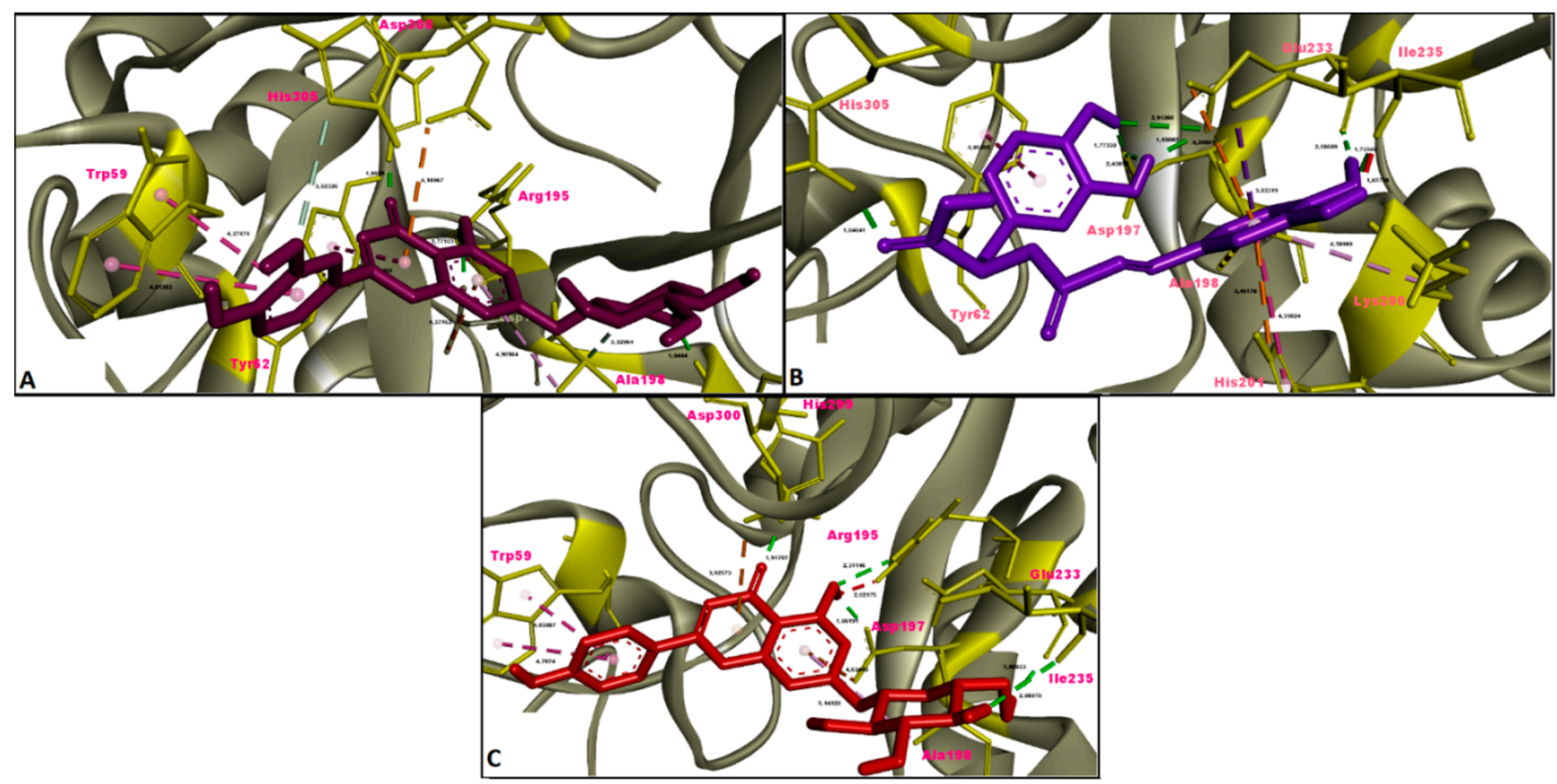

Figure 5. Molecular interaction between acetylcholinesterase (AChE) and (A) luteolin 7-glucoside, (B) rosmarinic acid and (C) apigenin 7-glucoside. 


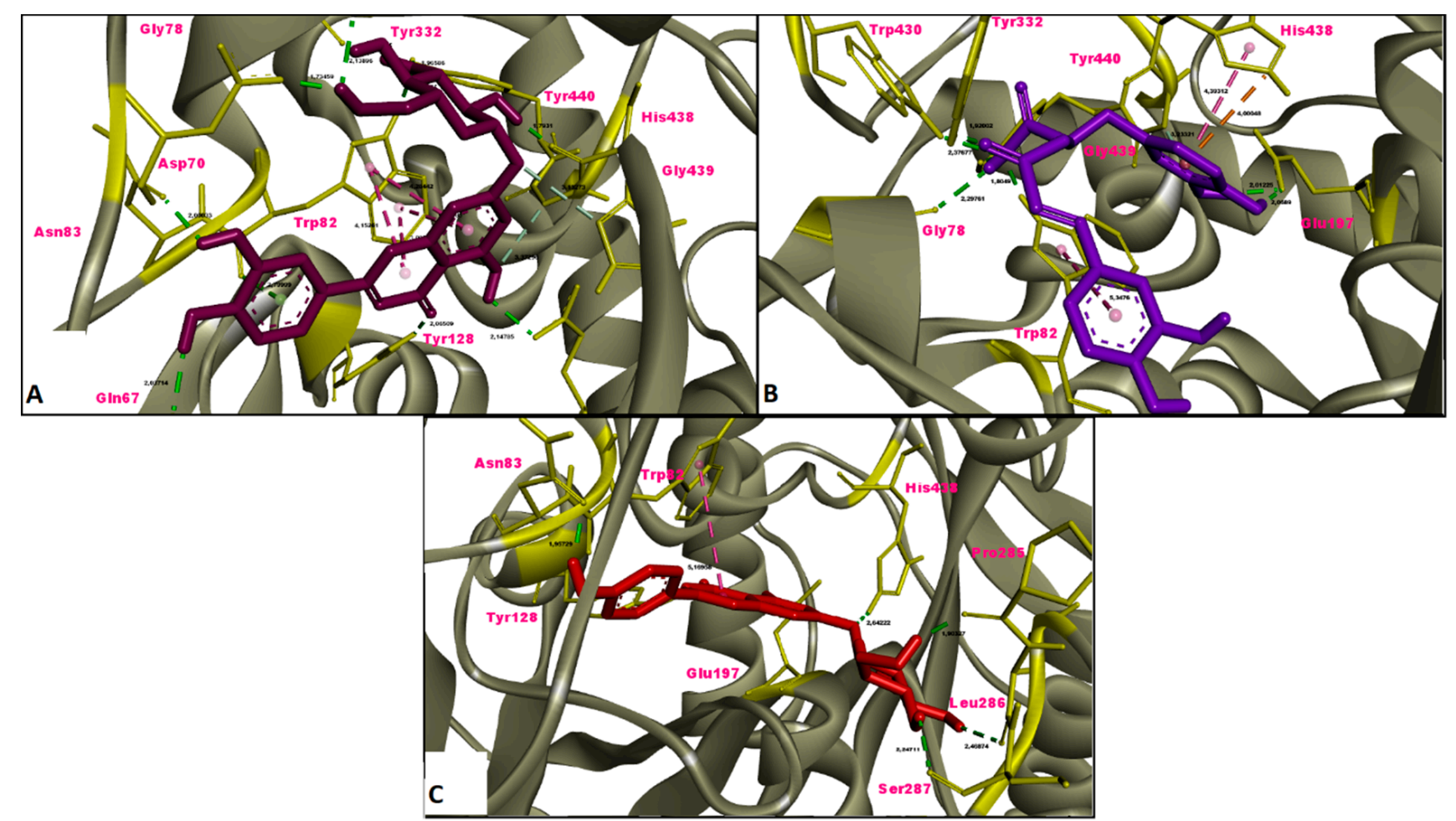

Figure 6. Molecular interaction between butyrylcholinesterase (BChE) and (A) luteolin 7-glucoside, (B) rosmarinic acid and (C) apigenin 7-glucoside.

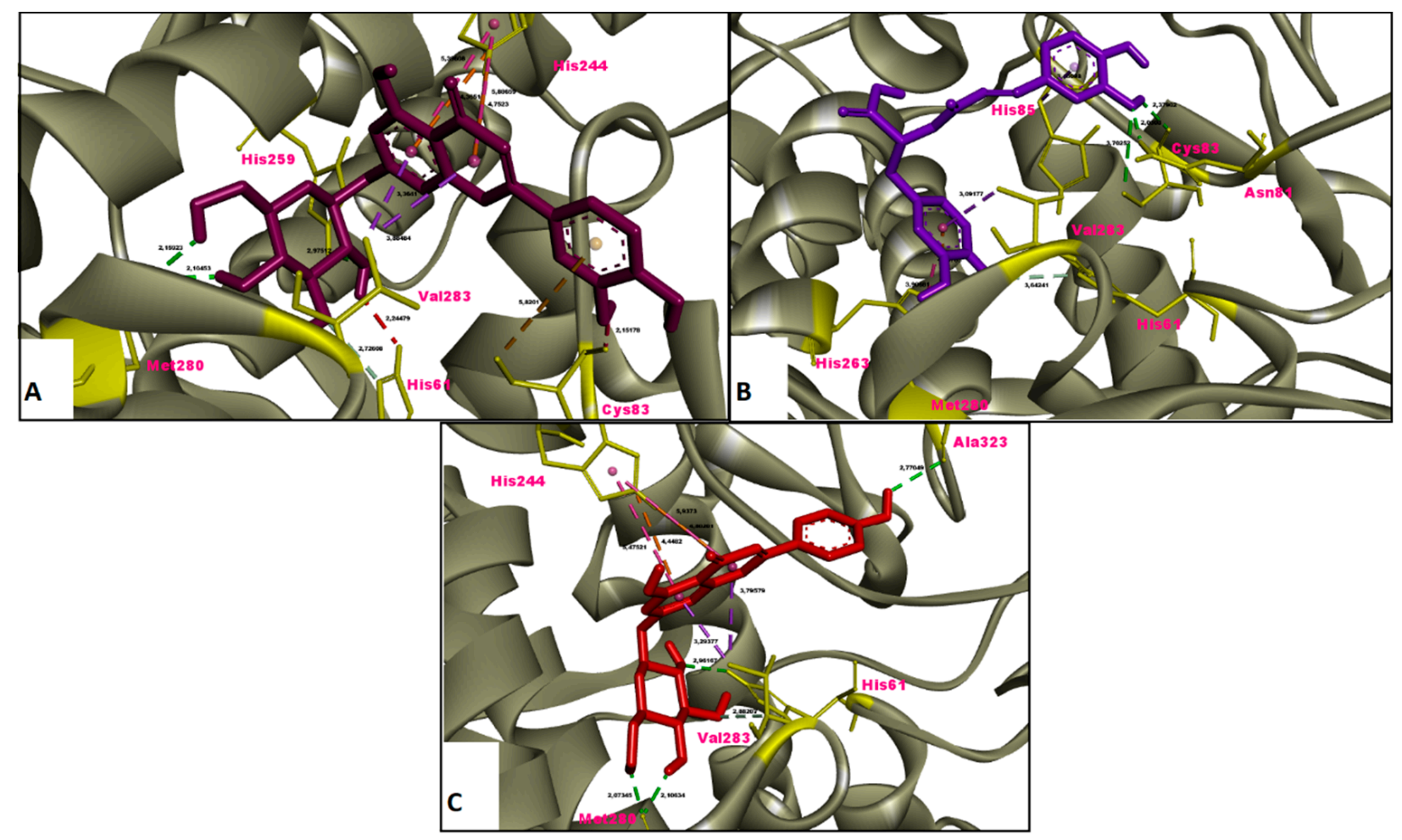

Figure 7. Molecular interaction between tyrosinase and (A) luteolin 7-glucoside, (B) rosmarinic acid and (C) apigenin 7-glucoside. 


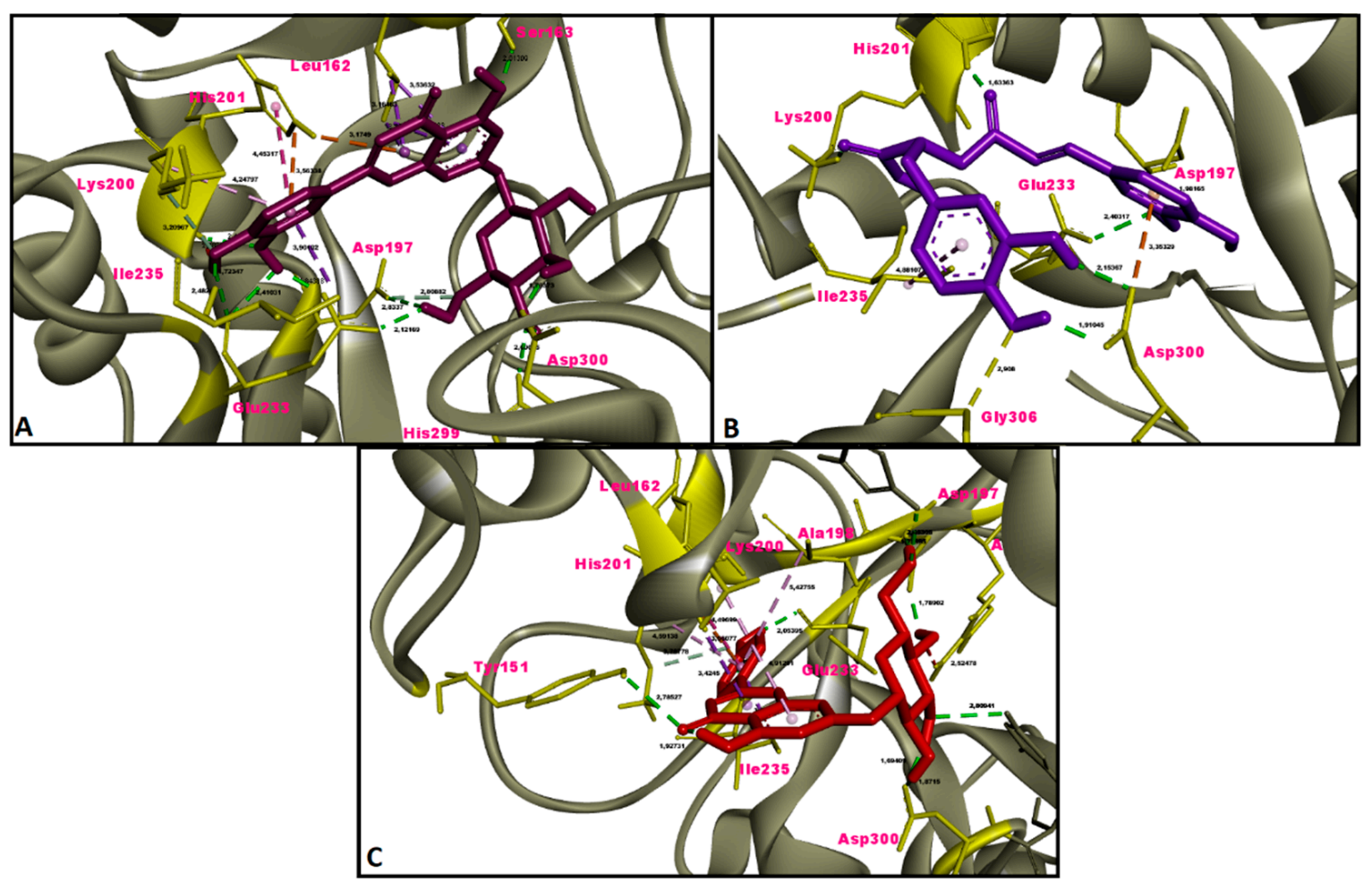

Figure 8. Molecular interaction between $\alpha$-amylase and (A) luteolin 7-glucoside, (B) rosmarinic acid and (C) apigenin 7-glucoside.

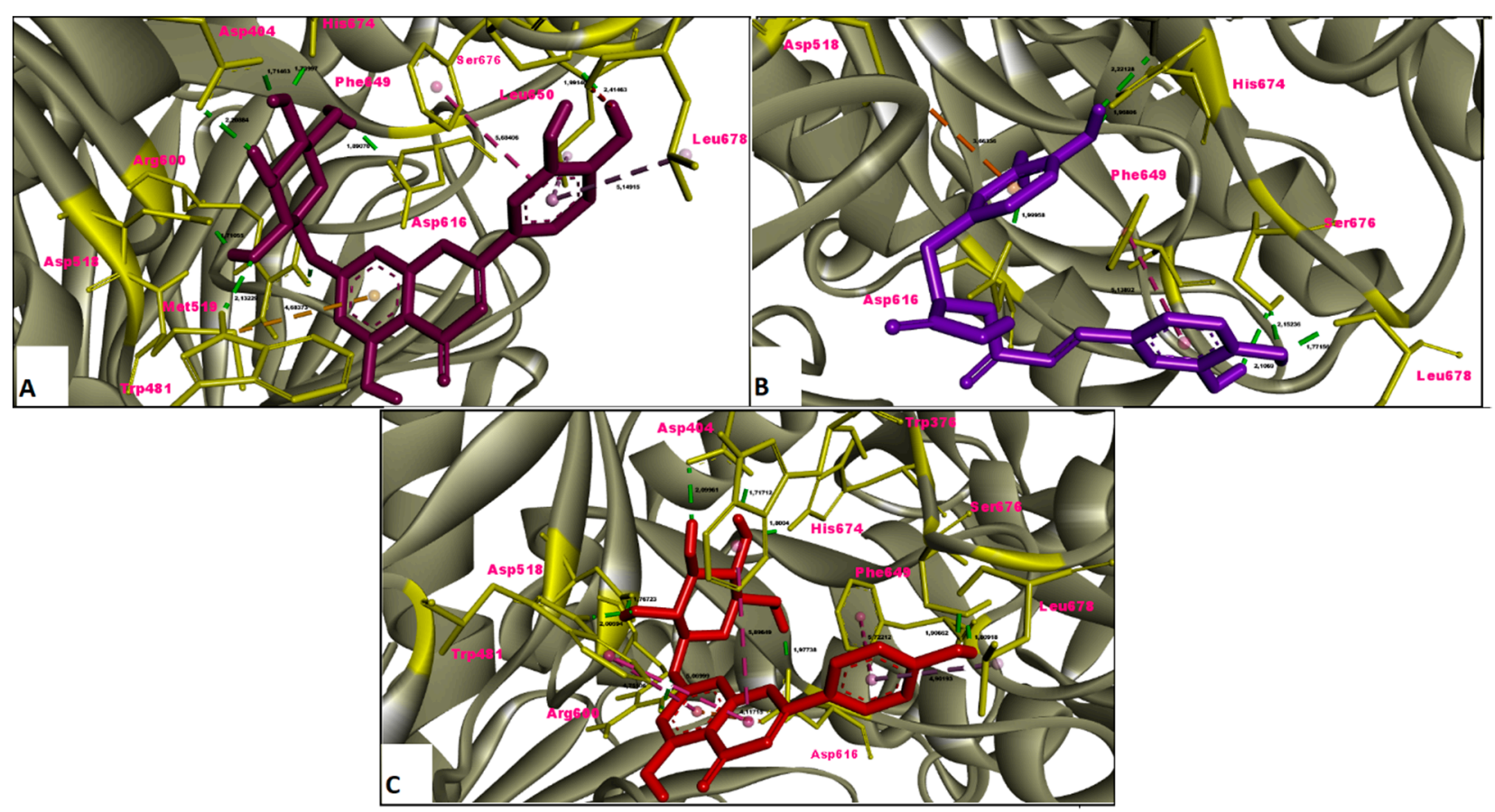

Figure 9. Molecular interaction between $\alpha$-glucosidase and (A) luteolin 7-glucoside, $(\mathbf{B})$ rosmarinic acid and (C) apigenin 7-glucoside.

\section{Discussion}

As far as could be ascertained from a literature survey, the chemical composition, antioxidant and enzyme inhibitory activities of the Onosma species evaluated here have not previously been reported elsewhere. Therefore, data presented here could be assumed as the first report on phytochemicals and aforementioned activities of these species. However, there are some literature data regarding the contribution of phytochemicals, which were 
determined as the major compounds in the current study, to antioxidant and enzyme inhibitory activity. These literature data were discussed in detail below.

In previous studies, it was reported that some Onosma and Anthemis species were to be rich in apigenin 7-glucoside showing significant antioxidant activity $[5,26,29,30]$. There were also some studies in the literature published by other research groups that this compound may positively affect antioxidant activity. Ozcan et al. [31] have investigated the effect of fermentation and bud size on chemical composition and antioxidant activity in capers. They found that the antioxidant activity of fresh material was higher than that of fermented one and apigenin 7-glucoside was reported to be one of the main compounds of the fresh material. In another study investigating the antioxidant and protective effects of Rhanterium suaveolens on mouse erythrocytes against acetamiprid (ACT)-induced oxidative stress, significant increases in SOD, CAT, and GPx activities were found in mice treated with $R$. suaveolens at a dose of $300 \mathrm{mg} / \mathrm{kg}$. HPLC-DAD analysis showed that one of the main compounds of the extract was apigenin 7-glucoside and this compound can affected the activity positively [32].

As with apigenin 7-glucoside, previous studies also revealed that various Onosma species were also rich in luteolin 7-glucoside exhibiting significant antioxidant activities $[5,26,29,30]$. Additionally, it has been reported that the free radical scavenging and ferrous ion chelating activities of the hydro-alcoholic extract obtained from Fraxinus angustifolia were quite successful compared to vitamin $\mathrm{E}$, even acting as an effective chain-breaking antioxidant against lipoperoxyl radicals. In that study, HPLC-DAD analyzes showed that luteolin 3,7-glucoside was among the major compounds [33].

Essafi et al. [34] have attempted to correlate the activities and chemical compositions of Tunisian olive leaf extracts. They reported that the main components were luteolin 4-glucoside, luteolin 7-glucoside and apigenin 7-glucoside and these compounds exhibited significant DPPH radical scavenging activity. The antioxidant activity of rosmarinic acid has been reported by many researchers [35-39]. Therefore, rosmarinic acid was considered to have a positive effect on antioxidant activity. The literature data discussed above corroborate those derived from the present study.

There are various reports in the literature that rosmarinic acid and flavonoid glycosides showed inhibitory effect on digestive enzymes. Witkowska-Banaszczak et al. [40] reported that Succisa pratensis is an important herbal source containing luteolin and apigenin 7 glycosides, and these flavonoid glycosides isolated from the flowers and leaves of this plant significantly inhibit the activity of pancreatic $\alpha$-amylase. Findings from the study conducted by Ma et al. [41] also supported those reported by Witkowska-Banaszczak et al. [40]. In the study reported by Ma et al. [41], as a result of the chemical characterization of the polyphenols of Sphallerocarpus gracilis stems and leaves, luteolin 7-glucoside was identified as the main component, and the extract was reported to have a dose-dependent inhibitory effect on $\alpha$-glucosidase. According to the literature data, rosmarinic acid is also among the phytochemicals that show inhibitory activity on digestive enzymes. Deng et al. [42] reported that Ehretia macrophylla, which is rich in rosmarinic acid, showed promising hypoglycemic activity by inhibiting $\alpha$-glucosidase and $\alpha$-amylase.

The tyrosinase inhibitory activities of flavonoid glycosides, which were reported as the major compounds in the present study, have not been studied before. However, in previous studies, some plant species rich in these flavonoid glycosides have been found to exhibit significant tyrosinase inhibitory activity $[5,26,29,30,43]$. However, data reported by Bouzaiene et al. [44] was in contradiction with the literature data presented above. According to Bouzaiene et al. [44], apigenin 7-glucoside increased tyrosinase activity in B16F10 melanoma cells and, consequently, melanin synthesis. To better understand the inhibitory activities of the flavonoid glycosides in question on tyrosinase, it was thought that the individual activities of these compounds should be tested. In contrast to the flavonoid glycosides mentioned above, there was evidence that rosmarinic acid has tyrosinase inhibitory activity. Monophenolase and diphenolase inhibitory activities of rosmarinic acid isolated from ethanol (EtOH) extract of Lepechinia meyenii were reported to be 4.14 and $8.59 \mu \mathrm{M}$, 
respectively [45]. However, in molecular docking calculations, a strong binding affinity of rosmarinic acid with tyrosinase was not found.

The cholinesterase inhibitory activities of flavonoid glycosides have not been studied before. Therefore, as stated above, further testing of individual inhibitory activities of these phytochemicals will help to elucidate the chemical composition-activity relationship in future studies. However, published data on the inhibitory activities of rosmarinic acid are clearer. Bilska et al. [46] have studied the activities of Rosmarinus officinalis of which major compound was rosmarinic acid. They reported that the AChE inhibitory activity of rosemary was higher than $\mathrm{BChE}$ inhibitory activity. This difference in inhibitory activity against cholinesterases was in correlation with those obtained from the present study.

In the present study, molecular docking calculations were also performed to evaluate the inhibitory activity of the main components on the enzymes in question. In the comparison of inhibitory activity, binding affinity values of co-crystallized ligands of these enzymes were used as positive controls. Molecular docking is a key technique in structural molecular biology and its purpose is to predict the primary (predominant) binding mode(s) and binding affinity of a ligand that complexes with a protein of known three-dimensional structure [47]. In this study, molecular docking analyzes were performed to estimate the binding modes and binding affinities of the identified three major compounds with tyrosinase, $\alpha$-amylase, $\alpha$-glucosidase and ChEs enzymes. The binding affinity $\left(\Delta \mathrm{G}^{\circ} ; \mathrm{kcal} / \mathrm{mol}\right)$ and inhibition constant $\left(\mathrm{K}_{\mathrm{i}}, \mathrm{mM}\right)$ values of main compounds against studied enzymes were shown in Table 3 and the top ranked receptor-ligand conformations were given in Figures 5-9. Of particular importance, the flavonoid glycosides (luteolin 7-glucoside and apigenin 7-glucoside) showed highly favourable free energy of binding against ChEs, tyrosinase, $\alpha$-amylase and $\alpha$-glucosidase when compared with positive controls. Thus, the data from this study show that the flavonoid glycosides can act as effective inhibitors on cholinesterases, tyrosinase and digestive enzymes.

\section{Materials and Methods}

\subsection{Plant Material}

The aerial parts of Onosma bourgaei Boiss. (1608 m., 40 $33^{\prime} 50^{\prime \prime}$ N 39 $24^{\prime} 15^{\prime \prime}$ E, Herbarium number: OC.5045) and Onosma trachytricha Boiss. (1169 m., 40 $31^{\prime} 48^{\prime \prime} \mathrm{N} 39^{\circ} 23^{\prime} 39^{\prime \prime}$ E, Herbarium number: OC.5046) were collected from Gumushane-Turkey in 2019. The plants were identified and deposited by Dr. Olcay Ceylan from the Department of Biology, Mugla Sitki Kocman University, Mugla-Turkey.

\subsection{Extraction Process}

Samples of five grams from the dried aerial parts were weighed and macerated in $100 \mathrm{~mL}$ of $\mathrm{MeOH}$ for $24 \mathrm{~h}$. Extraction with $\mathrm{MeOH}$ was repeated once more. The $\mathrm{MeOH}$ extracts obtained after the first and second maceration operations were combined and the $\mathrm{MeOH}$ was removed under vacuum. The yields of $O$. bourgaei and $O$. trachytricha extracts stored at $+4{ }^{\circ} \mathrm{C}$ were $11.71 \%$ and $6.32 \%(w / w)$, respectively.

\subsection{Chemical Composition Analysis}

Chemical compositions of O. bourgaei and O. trachytricha were first analyzed qualitatively [48]. Subsequently, amounts of selected compounds in the extracts were determined chromatographically [49].

For total phenolic content, sample solution $(0.25 \mathrm{~mL})$ was mixed with diluted FolinCiocalteu reagent $(1 \mathrm{~mL}, 1: 9)$ and shaken vigorously. After $3 \mathrm{~min}, \mathrm{Na}_{2} \mathrm{CO}_{3}$ solution $(0.75 \mathrm{~mL}$, $1 \%$ ) was added and the sample absorbance was read at $760 \mathrm{~nm}$ after $2 \mathrm{~h}$ incubation at room temperature. Total phenolic content was expressed as equivalents of gallic acid.

For total flavonoid content, sample solution $(1 \mathrm{~mL})$ was mixed with the same volume of aluminium trichloride $(2 \%)$ in methanol. Similarly, a blank was prepared by adding sample solution $(1 \mathrm{~mL})$ to methanol $(1 \mathrm{~mL})$ without $\mathrm{AlCl}_{3}$. The sample and blank absorbance were read at $415 \mathrm{~nm}$ after $10 \mathrm{~min}$ incubation at room temperature. Absorbance of the blank was 
subtracted from that of the sample. Total flavonoid content was expressed as equivalents of quercetin.

A 1260 Infinity liquid chromatography system (Agilent Technologies, Santa Clara, CA, USA) hyphenated to a 6420 Triple Quad mass spectrometer was used for quantitative analyses. Chromatographic separation was carried out on a Poroshell 120 EC-C18 $(100 \mathrm{~mm} \times 4.6 \mathrm{~mm}$ I.D., $2.7 \mu \mathrm{m})$ column. Three mobile phases were tested to obtain a complete resolution of all isomers and the highest sensitivity for all target compounds, namely: (i) $0.1 \%$ formic acid/methanol, (ii) $5 \mathrm{mM}$ ammonium acetate/acetonitrile with $0.1 \%$ acetic acid and (iii) $10 \mathrm{mM}$ ammonium formate with $0.1 \%$ formic acid/acetonitrile with $0.1 \%$ formic acid, respectively. The first mobile phase configuration $(0.1 \%$ formic acid $/ \mathrm{methanol})$ was selected on the base of the better chromatographic resolution of isomeric compounds. On the other hand, the selected mobile phase configuration also provided higher sensitivity for many of the phenolic compounds. As a result, the mobile phase was made up from solvent A $(0.1 \%, v / v$ formic acid solution) and solvent B (methanol). The gradient profile was set as follows: $0.00 \mathrm{~min} 2 \%$ B eluent, $3.00 \mathrm{~min} 2 \%$ B eluent, $6.00 \mathrm{~min} 25 \%$ B eluent, $10.00 \mathrm{~min} 50 \%$ B eluent, $14.00 \mathrm{~min} 95 \%$ B eluent, $17.00 \mathrm{~min} 95 \% \mathrm{~B}$ and $17.50 \mathrm{~min} 2 \% \mathrm{~B}$ eluent. The column temperature was maintained at $25^{\circ} \mathrm{C}$. The flow rate was $0.4 \mathrm{~mL} \mathrm{~min}{ }^{-1}$ and the injection volume was $2.0 \mu \mathrm{L}$.

The tandem mass spectrometer was interfaced to the LC system via an ESI source. The electrospray source of the MS was operated in negative and positive multiple reaction monitoring (MRM) mode and the interface conditions were as follows: capillary voltage of $-3.5 \mathrm{kV}$, gas temperature of $300{ }^{\circ} \mathrm{C}$ and gas flow of $11 \mathrm{~L} \mathrm{~min}^{-1}$. The nebulizer pressure was 40 psi.

\subsection{Antioxidant and Enzyme Inhibitory Activities}

Antioxidant [48,50-53] and enzyme inhibitory activities of $O$. bourgaei and O. trachytricha extracts were carried out following the methods given in the literature [28]. Total antioxidant activity of the samples was evaluated by phosphomolybdenum method. Sample solution $(0.2 \mathrm{~mL})$ was combined with $2 \mathrm{~mL}$ of reagent solution $(0.6 \mathrm{M}$ sulfuric acid, $28 \mathrm{mM}$ sodium phosphate and $4 \mathrm{mM}$ ammonium molybdate). The sample absorbance was read at $695 \mathrm{~nm}$ after $90 \mathrm{~min}$ incubation at $95^{\circ} \mathrm{C}$.

For 1,1-diphenyl-2-picrylhydrazyl (DPPH) radical scavenging activity, sample solution $(1 \mathrm{~mL})$ was added to a $4 \mathrm{~mL}$ of $0.004 \%$ methanol solution of DPPH. Sample absorbance was read at $517 \mathrm{~nm}$ after $30 \mathrm{~min}$ incubation at room temperature in dark.

For ABTS cation radical scavenging activity, briefly, $\mathrm{ABTS}^{+}$radical cation was produced directly by reacting $7 \mathrm{mM}$ ABTS solution with $2.45 \mathrm{mM}$ potassium persulfate and allowing the mixture to stand for $12-16 \mathrm{~h}$ in dark at the room temperature. Prior to beginning the assay, ABTS solution was diluted with methanol to obtain an absorbance of $0.700 \pm 0.02$ at $734 \mathrm{~nm}$. Sample solution $(1 \mathrm{~mL})$ was added to ABTS solution $(2 \mathrm{~mL})$ and mixed. Sample absorbance was read at $734 \mathrm{~nm}$ after $7 \mathrm{~min}$ incubation at room temperature.

For metal chelating activity on ferrous ions, briefly, sample solution $(2 \mathrm{~mL})$ was added to $\mathrm{FeCl}_{2}$ solution $(0.05 \mathrm{~mL}, 2 \mathrm{mM})$. The reaction was initiated by the addition of $5 \mathrm{mM}$ ferrozine $(0.2 \mathrm{~mL})$. Similarly, a blank was prepared by adding sample solution $(2 \mathrm{~mL})$ to $\mathrm{FeCl}_{2}$ solution $(0.05 \mathrm{~mL}, 2 \mathrm{mM})$ and water $(0.2 \mathrm{~mL})$ without ferrozine. Then, the sample and blank absorbance were read at $562 \mathrm{~nm}$ after $10 \mathrm{~min}$ incubation at room temperature.

For cupric ion reducing activity (CUPRAC), sample solution $(0.5 \mathrm{~mL})$ was added to a premixed reaction mixture containing $\mathrm{CuCl}_{2}(1 \mathrm{~mL}, 10 \mathrm{mM})$, neocuproine $(1 \mathrm{~mL}, 7.5 \mathrm{mM})$ and $\mathrm{NH}_{4}$ Ac buffer $(1 \mathrm{~mL}, 1 \mathrm{M}, \mathrm{pH} 7.0)$. Similarly, a blank was prepared by adding sample solution $(0.5 \mathrm{~mL})$ to a premixed reaction mixture $(3 \mathrm{~mL})$ without $\mathrm{CuCl}_{2}$. Then, the sample and blank absorbance were read at $450 \mathrm{~nm}$ after $30 \mathrm{~min}$ incubation at room temperature.

For ferric reducing antioxidant power (FRAP), sample solution $(0.1 \mathrm{~mL})$ was added to a premixed FRAP reagent $(2 \mathrm{~mL})$ containing acetate buffer $(0.3 \mathrm{M}, \mathrm{pH} 3.6), 2,4,6$-tris(2pyridyl)- s-triazine (TPTZ) $(10 \mathrm{mM})$ in $40 \mathrm{mM} \mathrm{HCl}$ and ferric chloride $(20 \mathrm{mM})$ in a ratio of 
10:1:1 $(v / v / v)$. Then, the sample absorbance was read at $593 \mathrm{~nm}$ after $30 \mathrm{~min}$ incubation at room temperature.

Inhibitory activity on $\alpha$-amylase was performed using Caraway-Somogyi iodine/potassium iodide (IKI) method. Sample solution $(25 \mu \mathrm{L})$ was mixed with $\alpha$-amylase solution $(50 \mu \mathrm{L})$ in phosphate buffer ( $\mathrm{pH} 6.9$ with $6 \mathrm{mM}$ sodium chloride) in a 96-well micro plate and incubated for $10 \mathrm{~min}$ at $37^{\circ} \mathrm{C}$. After pre-incubation, the reaction was initiated by the addition of starch solution $(50 \mu \mathrm{L}, 0.05 \%)$. Similarly, a blank was prepared by adding sample solution to all reaction reagents without enzyme solution ( $\alpha$-amylase). The reaction mixture was incubated $10 \mathrm{~min}$ at $37^{\circ} \mathrm{C}$. The reaction was then stopped with the addition of $\mathrm{HCl}(25 \mu \mathrm{L}, 1 \mathrm{M})$. This was followed by the addition of iodine-potassium iodide solution $(100 \mu \mathrm{L})$. The sample and blank absorbance were read at $630 \mathrm{~nm}$. Absorbance of the blank was subtracted from that of the sample.

Tyrosinase inhibitory activity was measured using a modified dopachrome method with L- DOPA as substrate. Sample solution $(25 \mu \mathrm{L})$ was mixed with tyrosinase solution $(40 \mu \mathrm{L})$ and phosphate buffer $(100 \mu \mathrm{L}, \mathrm{pH} 6.8)$ in a 96 -well microplate and incubated for $15 \mathrm{~min}$ at $25^{\circ} \mathrm{C}$. The reaction was then initiated with the addition of L-DOPA $(40 \mu \mathrm{L})$. Similarly, a blank was prepared by adding sample solution to all reaction reagents without enzyme (tyrosinase) solution. The sample and blank absorbance were read at $492 \mathrm{~nm}$ after 10 min incubation at $25^{\circ} \mathrm{C}$.

Cholinesterase (ChE) inhibitory activity was measured using Ellman's method. Sample solution $(50 \mu \mathrm{L})$ was mixed with DTNB $(125 \mu \mathrm{L})$ and AChE (or BChE) solutions $(25 \mu \mathrm{L})$ in Tris-HCl buffer ( $\mathrm{pH} 8.0$ ) in a 96-well microplate and incubated for 15 min at $25^{\circ} \mathrm{C}$. The reaction was then initiated with the addition of acetylthiocholine iodide (ATCI) or butyrylthiocholine chloride (BTCl) $(25 \mu \mathrm{L})$. Similarly, a blank was prepared by adding sample solution to all reaction reagents without enzyme solutions (AChE or BChE). The sample and blank absorbance were read at $405 \mathrm{~nm}$ after $10 \mathrm{~min}$ incubation at $25^{\circ} \mathrm{C}$. Absorbance of the blank was subtracted from that of the sample.

For $\alpha$-glucosidase inhibitory activity, sample solution $(50 \mu \mathrm{L})$ was mixed with glutathione $(50 \mu \mathrm{L}), \alpha$-glucosidase solution $(50 \mu \mathrm{L})$ in phosphate buffer ( $\mathrm{pH}$ 6.8) and PNPG $(50 \mu \mathrm{L})$ in a $96-$-well microplate and incubated for $15 \mathrm{~min}$ at $37^{\circ} \mathrm{C}$. Similarly, a blank was prepared by adding sample solution to all reaction reagents without enzyme ( $\alpha$-glucosidase) solution. The reaction was then stopped with the addition of sodium carbonate $(50 \mu \mathrm{L}$, $0.2 \mathrm{M}$ ). The sample and blank absorbance were read at $400 \mathrm{~nm}$. Absorbance of the blank was subtracted from that of the sample.

The in vitro activities of the extracts were expressed as $\mathrm{mg}$ standard equivalent/g extract and compared with those of the standards, including trolox, ethylenediaminetetraacetic acid (disodium salt) (EDTA), galanthamine, kojic acid, and acarbose, used as positive controls.

\subsection{In Silico Molecular Docking Analysis}

The protein data bank (pdb) files of all the ligands (luteolin-7-glucoside, rosmarinic acid and apigenin-7-glucoside) were downloaded from PubChem (https:/ / pubchem.ncbi. nlm.nih.gov) (accessed on 5 March 2021). In the Avogadro platform, the atom types and electrical charges of the ligands were optimized with MMFF94 force field using the steepest descent algorithm. The 3D structures of human pancreatic alpha-amylase (PDB ID: 1B2Y), human butyrylcholinesterase (PDB ID: 4BDS), recombinant human acetylcholinesterase (PDB ID: 4EY6), tyrosinase from Bacillus megaterium (PDB ID: 5I38) and human lysosomal acid-alpha-glucosidase (PDB ID: 5NN8) were downloaded from protein data bank (https:/ / www.rcsb.org/) (accessed on 5 March 2021) and thereafter the crude protein structures were refined by removing redundant subunits, bound inhibitors and all other heteroatoms which are not functional in molecular docking simulations. The regions where the catalytic amino acids of the enzymes are located were determined by viewing the amino acid residues with which the co-crystallized ligand interacts in the Discovery Studio v16 software. 
Molecular docking simulations between five enzymes and three ligands were undertaken using AutoDock 4.2.6 and the docking scores (binding free energies) of the ligands against pancreatic alpha-amylase, butyrylcholinesterase, recombinant human acetylcholinesterase, tyrosinase and alpha-glucosidase were subsequently calculated. In addition, for internal control purposes, enzymes were also redocked with their co-crystallized ligands and these binding affinity values obtained were used as positive controls for comparison [54-56]. For the preparation of the target and ligand molecules as well as the parameters prior to initiating the docking simulations using AutoDock 4.2.6, AutoDockTools-1.5.6 was used.

In this study, the grid box coordinates used in molecular docking simulations were adjusted to ensure that the tested three phytochemicals interact with the catalytic amino acid residues in the binding cavities of the enzymes in question.

Before molecular docking simulations, polar hydrogen atoms of the receptor and the ligand molecules were retained, while nonpolar hydrogens were merged and then, the Gasteiger charges of the ligands were calculated and the Kollmann charges were added for all the receptors with AutoDockTools-1.5.6. During the docking experiments, all the rotatable bonds of the ligands were set free and then the optimized protein (rigid) and ligand (flexible) structures were saved in PDBQT format. Grid box sizes were adjusted as: (a) $82 \times 56 \times 54 \AA$ points for the acetylcholinesterase; (b) $70 \times 62 \times 54 \AA$ points for butyrylcholinesterase; (c) $48 \times 50 \times 52 \AA$ points for tyrosinase; (d) $40 \times 40 \times 40 \AA$ points for alpha-amylase and, (e) $50 \times 40 \times 50 \AA$ points for alpha-glucosidase, respectively. These grid box sizes were initially determined to cover the catalytic amino acid residues of all the enzymes studied.

In all docking simulations, 100 genetic algorithm (GA) runs using an initial population of 150 individuals, maximum number of 5,000,000 energy evaluations, and a maximum number of 27,000 generations were selected. The values of 0.02 and 0.8 were chosen as the default parameters for mutation and crossover rates, respectively. After 100 independent docking calculations, all the possible binding modes (conformations) of the ligands were clustered by the program and were ranked based on the most negative binding free energy $(\mathrm{kcal} / \mathrm{mol})$ of the ligand conformation. The best docking poses obtained using the AutoDock 4.2 .6 between the ligand and receptor structures were analyzed with the BIOVIA Discovery Studio Visualizer v16.

\subsection{Statistical Analysis}

All in vitro tests were repeated three times to increase the scientific consistency of the results. The results are presented as mean value and standard deviation (mean \pm SD). Student's $t$-test with $\alpha=0.05$ (SPSS v. 22.0) was applied to detect the statistical similarities/differences between the data.

\section{Conclusions}

The fact that $O$. trachytricha, which was richer in most of the phytochemicals given in Table 2, is more active than $O$. bourgaei as an antioxidant, as expected, confirmed the view that the chemical composition has a determining effect on antioxidant activity. However, as evident from enzyme inhibition tests, $O$. trachytricha extract showed significantly higher activity only in BChE inhibition test compared to O. bourgaei extract. This suggests that specific components, rather than the overall extract composition, are responsible for enzyme inhibitory activity. When evaluated in combination with the results obtained from molecular docking analyses, it was found that the major components luteolin 7-glucoside and apigenin 7-glucoside showed the most important effect in enzyme inhibition activity and these two compounds can be recommended further as useful ligands for the inhibition of key enzymes that cause Alzheimer's disease, diabetes and hyperpigmentation disorder. Hopefully, these compounds have been experimentally shown to cross the blood-brain barrier [57,58].

Funding: This research received no external funding. 
Institutional Review Board Statement: Not applicable.

Informed Consent Statement: Not applicable.

Data Availability Statement: The data presented in this study are available on request from the corresponding author.

Acknowledgments: The author would like to thank to Olcay Ceylan for his kind help in identifying the plant materials used in this study. In addition, he would like to thank Cukurova University Scientific Research Projects Unit (BAP) for the convenience they provided in the use of high performance computer facility and softwares.

Conflicts of Interest: The author declare no conflict of interest.

Sample Availability: Samples of the compounds are not available from the author.

\section{References}

1. El-Shazly, A.; El-Domiaty, M.; Witte, L.; Wink, M. Pyrrolizidine alkaloids in members of the Boraginaceae from Sinai (Egypt). Biochem. Syst. Ecol. 1998, 26, 619-636. [CrossRef]

2. Özgen, U.; Coşkun, M.; Kazaz, C.; Secen, H. Naphthoquinones from the roots of Onosma argentatum Hub.-Mor. (Boraginaceae). Turk. J. Chem. 2004, 28, 451-454.

3. Noula, E.; Samanidou, V.F.; Assimopoulou, A.N.; Papageorgiou, V.P.; Papadoyannis, I.N. Solid-phase extraction for purification of alkannin/shikonin samples and isolation of monomeric and dimeric fractions. Anal. Bioanal. Chem. 2010, 397, 2221-2232. [CrossRef] [PubMed]

4. Pal, M.; Chaudhury, A. High frequency direct plant regeneration, micropropagation and shikonin induction in Arnebia hispidissima. J. Crop. Sci. Biotechnol. 2010, 13, 13-19. [CrossRef]

5. Sarikurkcu, C.; Sahinler, S.S.; Husunet, M.T.; Istifli, E.S.; Tepe, B. Two endemic Onosma species (O. sieheana and O. stenoloba): A comparative study including docking data on biological activity and phenolic composition. Ind. Crops Prod. 2020, 154, 112656. [CrossRef]

6. Özgen, U.; Houghton, P.; Ogundipe, Y.; Coşkun, M. Antioxidant and antimicrobial activities of Onosma argentatum and Rubia peregrina. Fitoterapia 2003, 74, 682-685. [CrossRef]

7. Sharma, S.; Khan, N.; Sultana, S. Effect of Onosma echioides on DMBA/croton oil mediated carcinogenic response, hyperproliferation and oxidative damage in murine skin. Life Sci. 2004, 75, 2391-2410. [CrossRef]

8. Mroczek, T.; Baj, S.; Chrobok, A.; Glowniak, K. Screening for pyrrolizidine alkaloids in plant materials by electron ionization RP-HPLC-MS with thermabeam interface. Biomed. Chromatogr. 2004, 18, 745-751. [CrossRef]

9. Naz, S.; Ahmad, S.; Rasool, S.A.; Sayeed, S.A.; Siddiqi, R. Antibacterial activity directed isolation of compounds from Onosma hispidum. Microbiol. Res. 2006, 161, 43-48. [CrossRef]

10. Aruoma, O.I. Free radicals, oxidative stress, and antioxidants in human health and disease. J. Am. Oil Chem. Soc. 1998, 75, 199-212. [CrossRef]

11. Del Rio, D.; Rodriguez-Mateos, A.; Spencer, J.P.; Tognolini, M.; Borges, G.; Crozier, A. Dietary (poly) phenolics in human health: Structures, bioavailability, and evidence of protective effects against chronic diseases. Antioxid. Redox Signal. 2013, 18, 1818-1892. [CrossRef]

12. Grosso, G.; Micek, A.; Godos, J.; Pajak, A.; Sciacca, S.; Galvano, F.; Giovannucci, E.L. Dietary flavonoid and lignan intake and mortality in prospective cohort studies: Systematic review and dose-response meta-analysis. Am. J. Epidemiol. 2017, 185, 1304-1316. [CrossRef]

13. Rienks, J.; Barbaresko, J.; Nöthlings, U. Association of polyphenol biomarkers with cardiovascular disease and mortality risk: A systematic review and meta-analysis of observational studies. Nutrients 2017, 9, 415.

14. Phan, M.A.T.; Wang, J.; Tang, J.; Lee, Y.Z.; Ng, K. Evaluation of $\alpha$-glucosidase inhibition potential of some flavonoids from Epimedium brevicornum. LWT Food Sci. Technol. 2013, 53, 492-498. [CrossRef]

15. Wang, Z.; Gao, X.; Li, W.; Tan, S.; Zheng, Q. Phenolic content, antioxidant capacity, and $\alpha$-amylase and $\alpha$-glucosidase inhibitory activities of Dimocarpus longan Lour. Food Sci. Biotechnol. 2019, 29, 683-692. [CrossRef]

16. Maack, A.; Pegard, A. Populus nigra (Salicaceae) absolute rich in phenolic acids, phenylpropanoïds and flavonoids as a new potent tyrosinase inhibitor. Fitoterapia 2016, 111, 95-101. [CrossRef]

17. Chang, V.; Teo, S. Evaluation of heavy metal, antioxidant and anti-tyrosinase activities of red seaweed (Eucheuma cottonii). Int Food Res. J. 2016, 23, 2370-2373.

18. Jeong, C.H.; Shim, K.H. Tyrosinase inhibitor isolated from the leaves of Zanthoxylum piperitum. Biosci. Biotechnol. Biochem. 2004, 68, 1984-1987. [CrossRef]

19. Chang, T.-S. An updated review of tyrosinase inhibitors. Int. J. Mol. Sci. 2009, 10, 2440-2475. [CrossRef]

20. Dolorosa, M.; Purwaningsih, S.; Anwar, E.; Hidayat, T. Tyrosinase Inhibitory Activity of Sargassum plagyophyllum and Eucheuma cottonii Methanol Extracts. In IOP Conference Series: Earth and Environmental Science; IOP Publishing: Bristol, UK, 2019 ; p. 012020. 
21. Micheau, J.; Marighetto, A. Acetylcholine and memory: A long, complex and chaotic but still living relationship. Behav. Brain Res. 2011, 221, 424-429. [CrossRef]

22. Mesulam, M.; Guillozet, A.; Shaw, P.; Quinn, B. Widely spread butyrylcholinesterase can hydrolyze acetylcholine in the normal and Alzheimer brain. Neurobiol. Dis. 2002, 9, 88-93. [CrossRef]

23. Öztaşkın, N.; Cetinkaya, Y.; Taslimi, P.; Göksu, S.; Gülçin, İ. Antioxidant and acetylcholinesterase inhibition properties of novel bromophenol derivatives. Bioorg. Chem. 2015, 60, 49-57. [CrossRef]

24. Bayrak, Ç.; Taslimi, P.; Gülçin, İ; Menzek, A. The first synthesis of 4-phenylbutenone derivative bromophenols including natural products and their inhibition profiles for carbonic anhydrase, acetylcholinesterase and butyrylcholinesterase enzymes. Bioorg. Chem. 2017, 72, 359-366. [CrossRef]

25. Anand, P.; Singh, B. A review on cholinesterase inhibitors for Alzheimer's disease. Arch. Pharm. Res. 2013, 36, 375-399. [CrossRef]

26. Sarikurkcu, C.; Sahinler, S.S.; Ceylan, O.; Tepe, B. Onosma ambigens: Phytochemical composition, antioxidant and enzyme inhibitory activity. Ind. Crops Prod. 2020, 154, 112651. [CrossRef]

27. Sarikurkcu, C.; Eskici, M.; Karanfil, A.; Tepe, B. Phenolic profile, enzyme inhibitory and antioxidant activities of two endemic Nepeta species: Nepeta nuda subsp. glandulifera and N. cadmea. S. Afr. J. Bot. 2019, 120, 298-301. [CrossRef]

28. Ozer, M.S.; Kirkan, B.; Sarikurkcu, C.; Cengiz, M.; Ceylan, O.; Atilgan, N.; Tepe, B. Onosma heterophyllum: Phenolic composition, enzyme inhibitory and antioxidant activities. Ind. Crops Prod. 2018, 111, 179-184. [CrossRef]

29. Sarikurkcu, C. Anthemis chia: Biological capacity and phytochemistry. Ind. Crops Prod. 2020, 153, 112578. [CrossRef]

30. Sarikurkcu, C.; Sahinler, S.S.; Tepe, B. Onosma aucheriana, O. frutescens, and O. sericea: Phytochemical profiling and biological activity. Ind. Crops Prod. 2020, 154, 112633. [CrossRef]

31. Ozcan, M.M.; Ahmed, I.A.M.; Al Juhaimi, F.; Uslu, N.; Osman, M.A.; Gassem, M.A.; Babiker, E.E.; Ghafoor, K. The influence of fermentation and bud sizes on antioxidant activity and bioactive compounds of three different size buds of Capparis ovata Desf. var. canescens plant. J. Food Sci. Technol. 2020, 57, 2705-2712. [CrossRef]

32. Chelly, S.; Chelly, M.; Ben Salah, H.; Athmouni, K.; Bitto, A.; Sellami, H.; Kallel, C.; Bouaziz-Ketata, H. HPLC-DAD analysis, antioxidant and protective effects of Tunisian Rhanterium suaveolens against acetamiprid induced oxidative stress on mice erythrocytes. Chem. Biodivers. 2019, 16, e1900428. [CrossRef]

33. Attanzio, A.; D’Anneo, A.; Pappalardo, F.; Bonina, F.P.; Livrea, M.A.; Allegra, M.; Tesoriere, L. Phenolic composition of hydrophilic extract of manna from sicilian Fraxinus angustifolia Vahl and its reducing, antioxidant and anti-inflammatory activity in vitro. Antioxidants 2019, 8, 494. [CrossRef]

34. Essafi, H.; Trabelsi, N.; Benincasa, C.; Tamaalli, A.; Perri, E.; Zarrouk, M. Phytochemical profile, antioxidant and antiproliferative activities of olive leaf extracts from autochthonous tunisian cultivars. Acta Aliment. 2019, 48, 384-390. [CrossRef]

35. Rahimmalek, M.; Afshari, M.; Sarfaraz, D.; Miroliaei, M. Using HPLC and multivariate analyses to investigate variations in the polyphenolic compounds as well as antioxidant and antiglycative activities of some Lamiaceae species native to Iran. Ind. Crops Prod. 2020, 154, 112640. [CrossRef]

36. Fateminasab, F.; Bordbar, A.K.; Shityakov, S.; Saboury, A.A. Molecular insights into inclusion complex formation between betaand gamma-cyclodextrins and rosmarinic acid. J. Mol. Liq. 2020, 314, 113802. [CrossRef]

37. Righi, N.; Boumerfeg, S.; Fernandes, P.A.R.; Deghima, A.; Baali, F.; Coelho, E.; Cardoso, S.M.; Coimbra, M.A.; Baghiani, A. Thymus algeriensis Bioss \& Reut: Relationship of phenolic compounds composition with in vitro/in vivo antioxidant and antibacterial activity. Food Res. Int. 2020, 136, 109500.

38. Selseleh, M.; Ebrahimi, S.N.; Aliahmadi, A.; Sonboli, A.; Mirjalili, M.H. Metabolic profiling, antioxidant, and antibacterial activity of some Iranian Verbascum L. species. Ind. Crops Prod. 2020, 153, 112609. [CrossRef]

39. Singh, A.; Srivastava, N.; Yadav, K.S.; Sinha, P.; Yadav, N.P. Preparation, optimization, characterization and bioevaluation of rosmarinic acid loaded phytovesicles for anti-inflammatory activity. J. Drug Deliv. Sci. Technol. 2020, 59, 101888. [CrossRef]

40. Witkowska-Banaszczak, E.; Krajka-Kuzniak, V.; Papierska, K. The effect of luteolin 7-glucoside, apigenin 7-glucoside and Succisa pratensis extracts on NF-kappa B activation and alpha-amylase activity in HepG2 cells. Acta Biochim. Pol. 2020, 67, 41-47.

41. Ma, T.T.; Sun, X.Y.; Tian, C.R.; Luo, J.Y.; Zheng, C.P.; Zhan, J.C. Enrichment and purification of polyphenol extract from sphallerocarpus gracilis stems and leaves and in vitro evaluation of DNA damage-protective activity and inhibitory effects of alpha-amylase and alpha-glucosidase. Molecules 2015, 20, 21442-21457. [CrossRef] [PubMed]

42. Deng, N.; Zheng, B.S.; Li, T.; Hu, X.D.; Liu, R.H. Phenolic profiles, antioxidant, antiproliferative, and hypoglycemic activities of Ehretia macrophyla Wall. (EMW) fruit. J. Food Sci. 2020, 85, 2177-2185. [CrossRef] [PubMed]

43. Kirkan, B. Antioxidant potential, enzyme inhibition activity, and phenolic profile of extracts from Stachys cretica subsp. vacillans. Ind. Crops Prod. 2019, 140, 111639. [CrossRef]

44. Bouzaiene, N.N.; Chaabane, F.; Sassi, A.; Chekir-Ghedira, L.; Ghedira, K. Effect of apigenin-7-glucoside, genkwanin and naringenin on tyrosinase activity and melanin synthesis in B16F10 melanoma cells. Life Sci. 2016, 144, 80-85. [CrossRef]

45. Crespo, M.I.; Chaban, M.F.; Lanza, P.A.; Joray, M.B.; Palacios, S.M.; Vera, D.M.A.; Carpinella, M.C. Inhibitory effects of compounds isolated from Lepechinia meyenii on tyrosinase. Food Chem. Toxicol. 2019, 125, 383-391. [CrossRef] [PubMed]

46. Bilska, A.; Kobus-Cisowska, J.; Kmiecik, D.; Danyluk, B.; Kowalski, R.; Szymanowska, D.; Gramza-Michalowska, A.; Szczepaniak, O. Cholinesterase inhibitory activity, antioxidative potential and microbial stability of innovative liver pate fortified with rosemary extract (Rosmarinus officinalis). Electron. J. Biotechnol. 2019, 40, 22-29. [CrossRef]

47. Morris, G.M.; Lim-Wilby, M. Molecular docking. Methods Mol. Biol. 2008, 443, 365-382. 
48. Zengin, G.; Sarikurkcu, C.; Gunes, E.; Uysal, A.; Ceylan, R.; Uysal, S.; Gungor, H.; Aktumsek, A. Two Ganoderma species: Profiling of phenolic compounds by HPLC-DAD, antioxidant, antimicrobial and inhibitory activities on key enzymes linked to diabetes mellitus, Alzheimer's disease and skin disorders. Food Funct. 2015, 6, 2794-2802. [CrossRef]

49. Cittan, M.; Çelik, A. Development and validation of an analytical methodology based on Liquid Chromatography-Electrospray Tandem Mass Spectrometry for the simultaneous determination of phenolic compounds in olive leaf extract. J. Chromatogr. Sci. 2018, 56, 336-343. [CrossRef]

50. Apak, R.; Güçlü, K.; Özyürek, M.; Esin Karademir, S.; Erçağ, E. The cupric ion reducing antioxidant capacity and polyphenolic content of some herbal teas. Int. J. Food Sci. Nutr. 2006, 57, 292-304. [CrossRef]

51. Kocak, M.S.; Sarikurkcu, C.; Cengiz, M.; Kocak, S.; Uren, M.C.; Tepe, B. Salvia cadmica: Phenolic composition and biological activity. Ind. Crops Prod. 2016, 85, 204-212. [CrossRef]

52. Tepe, B.; Sarikurkcu, C.; Berk, S.; Alim, A.; Akpulat, H.A. Chemical composition, radical scavenging and antimicrobial activity of the essential oils of Thymus boveii and Thymus hyemalis. Rec. Nat. Prod. 2011, 5, 208-220.

53. Zengin, G.; Sarikurkcu, C.; Uyar, P.; Aktumsek, A.; Uysal, S.; Kocak, M.S.; Ceylan, R. Crepis foetida L. subsp rhoeadifolia (Bleb.) Celak. as a source of multifunctional agents: Cytotoxic and phytochemical evaluation. J. Funct. Foods 2015, 17, 698-708. [CrossRef]

54. Sanner, M.F. Python: A programming language for software integration and development. J. Mol. Graph. Model. 1999, $17,57-61$.

55. Nasab, R.R.; Hassanzadeh, F.; Khodarahmi, G.A.; Rostami, M.; Mirzaei, M.; Jahanian-Najafabadi, A.; Mansourian, M. Docking study, synthesis and antimicrobial evaluation of some novel 4-anilinoquinazoline derivatives. Res. Pharm. Sci. 2017, 12, 425-433. [PubMed]

56. Ricci, C.G.; Netz, P.A. Docking studies on DNA-ligand interactions: Building and application of a protocol to identify the binding mode. J. Chem. Inf. Model. 2009, 49, 1925-1935. [CrossRef]

57. Qin, L.; Chen, Z.; Yang, L.; Shi, H.; Wu, H.; Zhang, B.; Zhang, W.; Xu, Q.; Huang, F.; Wu, X. Luteolin-7-O-glucoside protects dopaminergic neurons by activating estrogen-receptor-mediated signaling pathway in MPTP-induced mice. Toxicology 2019, 426, 152256. [CrossRef] [PubMed]

58. Salehi, B.; Venditti, A.; Sharifi-Rad, M.; Kregiel, D.; Sharifi-Rad, J.; Durazzo, A.; Lucarini, M.; Santini, A.; Souto, E.B.; Novellino, E.; et al. The Therapeutic Potential of Apigenin. Int. J. Mol. Sci. 2019, 20, 1305. [CrossRef] 